\title{
Coordination Behavior and Biological Activity of Some Transition Metal Complexes with 2-Acetyl and 2-Formyl-3-Amino-1,4-Naphthoquinone Ligands
}

\author{
Fatma S. M. Hassan ${ }^{*}$ (D), Mahmoud Fayez ${ }^{2}$, Nadia Abdalla ${ }^{1}$ \\ ${ }^{1}$ Chemistry Department, Faculty of Science, Aswan University, Aswan, Egypt \\ ${ }^{2}$ Luxor Company for Water and Wastewater, Luxor, Egypt \\ Email: ^fatma_smh@yahoo.com
}

How to cite this paper: Hassan, F.S.M., Fayez, M. and Abdalla, N. (2020) Coordination Behavior and Biological Activity of Some Transition Metal Complexes with 2-Acetyl and 2-Formyl-3-Amino-1,4-Naphthoquinone Ligands. Open Journal of Inorganic Non-metallic Materials, 10, 15-29. https://doi.org/10.4236/ojinm.2020.102002

Received: April 1, 2020

Accepted: April 25, 2020

Published: April 28, 2020

Copyright $\odot 2020$ by author(s) and Scientific Research Publishing Inc. This work is licensed under the Creative Commons Attribution International License (CC BY 4.0).

http://creativecommons.org/licenses/by/4.0/

\begin{abstract}
The aim of this work is to synthesize, characterize and evaluate the biological activity of 2-acetyl and 2-formyl-3-amino-1,4-naphthoquinone $\left(\mathrm{L}^{1}-\mathrm{L}^{2}\right)$ and their metal-Co(II), $\mathrm{Ni}(\mathrm{II})$ and $\mathrm{Cu}(\mathrm{II})$ chelates. The newly chelates were characterized by elemental analysis, IR, mass and ${ }^{1} \mathrm{HNMR}$ spectra, thermogravimetric analysis (TGA) and biological activity. The antibacterial and antifungal activities of the ligands and its metal complexes were screened against bacterial species (Staphylococcus aureus, Bacillus subtilis and Escherichia coli) and fungi (Candida albicans). Ampicillin and amphotericin were used as references for antibacterial and antifungal studies. The activity data show that the metal complexes have a promising biological activity comparable with parent free ligand against bacterial and fungal species.
\end{abstract}

\section{Keywords}

1,4-Naphthoquinone, Transition Metal Complex, Antibacterial Activity

\section{Introduction}

Chemical synthesis is a hot topic because of a global crisis of drug resistance, in pathogens of both clinical and agriculture importance. Many of these pathogens are resistant to multiple classes of antibiotics and is increasingly common for them to be resistant to practically all available drugs, leaving few alternatives for the treatment of infections, especially in immunocompromised patients [1] [2]. 
Despite addition of new classes of antimicrobials, the number of currently available drugs for infections treatment remains limited. Therefore, there is a continuing need to develop new, simpler, more effective and less toxic antimicrobials agents; so naphthoquinones and derivatives are a group of great importance that has attracted interest of the scientific community. Naphthoquinones are natural aromatic compounds that can be found in several plant families, as well as isolated of fungi, algae and bacteria. Traditionally used for their dyeing properties, however, recently a variety of biological activities of these compounds has been reported [3] [4]. In most cases, these pharmacological activities are related to redox and acid-base properties, which can be modulated synthetically by modifying the substituents attached to the 1,4-naphthoquinone ring, in order to enhance their therapeutic actions. At the present time, the synthetic methods should be designed according the principles of green chemistry to promote process more sustainable with the environmental and human safe. Because of this, in this chapter is described the chemistry and green synthesis of natural and synthetic naphthoquinones as potential antibacterial, antifungal, anti-parasitic and antiviral agents, as well as its mechanism of action. Contributing in the area of synthesis and screening of novel chemical compounds for antimicrobial action. Naphthoquinones are structurally related to naphthalene, are characterized by the presence of two carbonyl groups in the 1,4 position and 1,2 position with lower incidence, which are named as 1,4-naphthoquinones and 1,2-naphthoquinone respectively. Naturally present hydroxyl and methyl groups as substituents, can be found in free form or condensed with oligosaccharides. Naphthoquinones are highly reactive organic compounds, traditionally used as natural or synthetic dyes whose colors range from yellow to red [5] [6]. The effect of metal complexation on the antimicrobial activity of 1,4-naphthoquinones was investigated. Nickel-, chromium-, iron-, copper-, and cobalt-containing metal chelates of 5-amino-8hydroxy-1,4-naphtoquinone (2) and its acyl-derivatives $(3-8)$ were synthesized and characterized, and their antimicrobial activity was evaluated. Data from infrared spectroscopy indicate that naphthoquinones coordinate through oxygen and nitrogen atoms for (2), and through oxygen atoms when ligands were acyl derivatives $(3-8)$. Susceptibility tests for antimicrobial activity showed that 2 and its acyl derivatives were effective on inhibiting the growth of pathogenic bacteria such as Staphylococcus aureus, Streptococcus uberis and Bacillus cereus, but not Gram-negative bacteria. The metal complexation often caused decrease of biological activity. Nickel complex of (2) was the most effective against Gram-positive bacteria, showing MIC values ranging from 375 to $1400 \mathrm{mg} / \mathrm{ml}$. Metal chelates may be useful tools for the understanding of the antimicrobial mechanism of 1,4-naphthoquinones on these bacteria [5].

\section{Experimental}

\subsection{Materials and Reagents}

Analytical grade chemical reagents were used. All chemicals used in this study 
are of the highest purity from commercial suppliers such as Merck; $\mathrm{BDH}$ and Aldrich they include 1,4-Naphthoquinone, Acetamide and Formamide, $\mathrm{CoCl}_{2} \cdot 6 \mathrm{H}_{2} \mathrm{O}$, $\mathrm{NiCl}_{2} \cdot 6 \mathrm{H}_{2} \mathrm{O}$ and $\mathrm{CuCl}_{2} \cdot 2 \mathrm{H}_{2} \mathrm{O}$. The organic solvents such as absolute ethanol and methanol, DMF and DMSO are purchased from Alpha Easer.

\subsection{Instrumentation}

Melting point apparatus (Gallen Kamp, Germany) was used to investigate the melting points. Elemental microanalysis of the separated solid chelates for $\mathrm{C}, \mathrm{H}$ and $\mathrm{N}$ were performed in the Micro analytical Center, Cairo University, using CHNS-932(LECO) Vario Elemental analyzers. Infrared spectra were recorded on Perkin-Elmer FT-IR type 1650 spectrophotometer in wave number region $4000-40 \mathrm{~cm}^{-1}$. The spectra were recorded as $\mathrm{KBr}$ pellets. The ${ }^{1} \mathrm{H}$ NMR spectra were recorded using $300 \mathrm{MHz}$ Varian-Oxford Mercury. The deuterated solvent used was dimethylsulphoxide (DMSO- $\mathrm{d}_{6}$ ) and the spectra extended from $0-15$ ppm. DTA-TG apparatus. The electron impact (EI) mass spectra (MS) at $70 \mathrm{eV}$ of the tested compounds has been done using MS-5988 GS-MS Hewlett-Packard instrument. TGA was carried out in dynamic nitrogen atmosphere $\left(10 \mathrm{~mL} \cdot \mathrm{min}^{-1}\right)$ with a heating rate of $10^{\circ} \mathrm{C} \cdot \mathrm{min}^{-1}$ using DTG-50 H Shimadzu simultaneous. The molar conductance of solid chelates in DMF was measured using WPA CM35 Conductivity meter fitted with platinized platinum electrodes. The antibacterial and antifungal activities were evaluated at the Microbiological laboratory, Micro analytical center, Cairo University, Egypt.

\subsection{Methods}

\subsubsection{Synthesis of Free Ligands}

1,4 Naphthoquinone ( $2 \mathrm{~g}, 0.0126 \mathrm{~mol})$ mixed with an equivalent amount $(0.74 \mathrm{~g}$, and $0.57 \mathrm{~g}, 0.0126 \mathrm{~mol}$ ) of acetamide and formamide respectively, then the mixture was added to an aqueous solution of sodium hydroxide and left for two hours on water bath to fused. The crude product was recrystallized from ethanol and dried under vacuum over $\mathrm{P}_{2} \mathrm{O}_{5}$. The yield was $90 \%$. The melting point was measured and listed in Table 1. The procedure cited in respective reference [7] [8].

\subsubsection{Preparation of Metal Complexes}

The metal complexes were prepared by dissolving (1075 g and $1.005 \mathrm{~g}, 0.005$ $\mathrm{mol}$ ) of ligand $\left(\mathrm{L}^{1}-\mathrm{L}^{2}\right)$ respectively in hot ethanol $(50 \mathrm{ml})$ and added drop wisely with stirring to a stoichiometric amount of 1:1 (M:L) molar ratio to $(1.189 \mathrm{~g}$, $1.888 \mathrm{~g}$, and $0.852 \mathrm{~g}, 0.005 \mathrm{~mol})$ of $\mathrm{CoCl}_{2} \cdot 6 \mathrm{H}_{2} \mathrm{O}, \mathrm{NiCl}_{2} \cdot 6 \mathrm{H}_{2} \mathrm{O}$ and $\mathrm{CuCl}_{2} \cdot 2 \mathrm{H}_{2} \mathrm{O}$ respectively. The reaction mixture was refluxed for $40 \mathrm{~min}$ and left overnight. The isolated solid complexes were filtered off, washed with distilled water until the solution became colorless and washed with $10 \mathrm{ml}$ hot ethanol-water mixture $(1: 1)$ to remove any traces of the unreacted materials. The solid complexes were dried at $70^{\circ} \mathrm{C}$ for several hours kept in desiccator containing dry $\mathrm{P}_{2} \mathrm{O}_{5}$. Analytical data were listed in Table 1. 
Table 1. Analytical and physical properties of 1,4-Naphthoquinone complexes.

\begin{tabular}{|c|c|c|c|c|c|c|c|c|}
\hline \multirow{2}{*}{$\begin{array}{c}\text { Compound } \\
\text { (Molecular formula) }\end{array}$} & \multirow[b]{2}{*}{ Color } & \multirow[b]{2}{*}{$\mathrm{m} \cdot \mathrm{p} \cdot{ }^{\circ} \mathrm{C}$} & \multicolumn{3}{|c|}{ \% Found (Calcd) } & \multirow[b]{2}{*}{ eff $\mu$} & \multirow{2}{*}{$\Omega \cdot \mathrm{mol}^{-1} \cdot \mathrm{cm}^{2}$} & \multirow{2}{*}{$\begin{array}{c}\text { Formula } \\
\text { weight }\end{array}$} \\
\hline & & & C & $\mathbf{H}$ & $\mathbf{N}$ & & & \\
\hline $\mathrm{L}^{1}\left[\mathrm{C}_{12} \mathrm{H}_{9} \mathrm{NO}_{3}\right]$ & Brown & 203 & $\begin{array}{c}66.92 \\
(66.97)\end{array}$ & $\begin{array}{c}4.16 \\
(4.21)\end{array}$ & $\begin{array}{c}6.46 \\
(6.50)\end{array}$ & - & - & 215.20 \\
\hline$\left[\mathrm{CoC}_{12} \mathrm{H}_{9} \mathrm{NO}_{3}\left(\mathrm{H}_{2} \mathrm{O}\right)_{2} \mathrm{Cl}_{2}\right] \cdot 4 \mathrm{H}_{2} \mathrm{O}$ & $\begin{array}{l}\text { Brown } \\
\text { reddish }\end{array}$ & 288 & $\begin{array}{c}31.75 \\
(31.80)\end{array}$ & $\begin{array}{c}4.63 \\
(4.67)\end{array}$ & $\begin{array}{c}3.04 \\
(3.09)\end{array}$ & - & 7.76 & 453.13 \\
\hline$\left[\mathrm{NiC}_{12} \mathrm{H}_{9} \mathrm{NO}_{3}\left(\mathrm{H}_{2} \mathrm{O}\right)_{2} \mathrm{Cl}_{2}\right] \cdot 4 \mathrm{H}_{2} \mathrm{O}$ & Brown & 333 & $\begin{array}{c}31.76 \\
(31.82)\end{array}$ & $\begin{array}{c}4.61 \\
(4.67)\end{array}$ & $\begin{array}{c}3.05 \\
(3.09)\end{array}$ & & 8.20 & 452.89 \\
\hline$\left[\mathrm{CuC}_{12} \mathrm{H}_{9} \mathrm{NO}_{3}\left(\mathrm{H}_{2} \mathrm{O}\right)_{2} \mathrm{Cl}_{2}\right]$ & $\begin{array}{l}\text { Brown } \\
\text { reddish }\end{array}$ & 302 & $\begin{array}{c}37.31 \\
(37.36)\end{array}$ & $\begin{array}{c}3.34 \\
(3.39)\end{array}$ & $\begin{array}{c}3.58 \\
(3.63)\end{array}$ & 2.86 & 5.55 & 385.68 \\
\hline $\mathrm{L}^{2}\left[\mathrm{C}_{11} \mathrm{H}_{7} \mathrm{NO}_{3}\right]$ & Brown & 134 & $\begin{array}{c}65.63 \\
(65.67)\end{array}$ & $\begin{array}{c}3.44 \\
(3.50)\end{array}$ & $\begin{array}{c}6.92 \\
(6.96)\end{array}$ & - & - & 201.17 \\
\hline$\left[\mathrm{CoC}_{11} \mathrm{H}_{7} \mathrm{NO}_{3}\left(\mathrm{H}_{2} \mathrm{O}\right)_{2} \mathrm{Cl}_{2}\right] \cdot 4 \mathrm{H}_{2} \mathrm{O}$ & $\begin{array}{l}\text { Brown } \\
\text { reddish }\end{array}$ & 218 & $\begin{array}{c}30.03 \\
(30.08)\end{array}$ & $\begin{array}{c}4.31 \\
(4.36)\end{array}$ & $\begin{array}{c}3.14 \\
(3.18)\end{array}$ & - & 6.84 & 439.10 \\
\hline$\left[\mathrm{NiC}_{11} \mathrm{H}_{7} \mathrm{NO}_{3}\left(\mathrm{H}_{2} \mathrm{O}\right)_{2} \mathrm{Cl}_{2}\right] \cdot 4 \mathrm{H}_{2} \mathrm{O}$ & Brown & 268 & $\begin{array}{c}30.05 \\
(30.10)\end{array}$ & $\begin{array}{c}4.32 \\
(4.36)\end{array}$ & $\begin{array}{c}3.14 \\
(3.19)\end{array}$ & - & 7.02 & 438.96 \\
\hline$\left[\mathrm{CuC}_{11} \mathrm{H}_{7} \mathrm{NO}_{3}\left(\mathrm{H}_{2} \mathrm{O}\right)_{2} \mathrm{Cl}_{2}\right]$ & Brown & 228 & $\begin{array}{c}35.48 \\
(35.54)\end{array}$ & $\begin{array}{c}2.93 \\
(2.98)\end{array}$ & $\begin{array}{c}3.72 \\
(3.76)\end{array}$ & 2.86 & 5.20 & 371.29 \\
\hline
\end{tabular}

eff $\mu$ : effective magnetic moment.

\subsection{Biological Activity}

Modified Kirby-Bauer disc diffusion method [9], has been used to determine the antimicrobial activity of the tested samples [10]. Examined $100 \mu$ of the tested bacteria or fungi and found it was developed in $10 \mathrm{ml}$ of fresh media until they reached a count of approximately $10^{8}$ cells $/ \mathrm{ml}$ for bacteria and 105 cells $/ \mathrm{ml}$ for fungi. $100 \mu \mathrm{l}$ of microbial suspension was spread onto agar plates corresponding to the broth in which they were maintained. Isolated colonies of each organism that might be playing a pathogenic role should be selected from primary agar plates and tested for susceptibility by disc diffusion method of the many media available, NCCLS recommends Mueller-Hinton agar due to it results in good batch-to-batch reproducibility. Disc diffusion method for filamentous fungi tested by using approved standard method (M38-A) developed. For evaluating the susceptibilities of filamentous fungi to antifungal agent. Disc diffusion method for yeast developed by National Committee for Clinical Laboratory Standards using approved standard method (M44-P). Plates inoculated with filamentous fungi as Asprgillus flavus at $25^{\circ} \mathrm{C}$ for 48 hours; Gram (+) bacteria as Staphylococcus aureus, Gram (-) bacteria as Escherichia coli, they were incubated at $35^{\circ} \mathrm{C}-37^{\circ} \mathrm{C}$ for $24-28$ hours and yeast as Candida albicans incubated at $30^{\circ} \mathrm{C}$ for $24-28$ hours, then the diameters of the inhibition zones were measured in millimeters with slipping calipers of the National Committee for clinical Laboratory Standards [11], have been used standard discs of tetracycline (antibacterial agent), and amphotericin B (antifungal agent) served as positive controls for antimicrobial activity but filter discs impregnated with $10 \mu \mathrm{l}$ of solvent (distilled 
water, chloroform, DMSO) were used as a negative control. The agar used is Mueller-Hinton agar that is rigorously tested for composition and $\mathrm{pH}$. Further the depth of the agar in the plate is a factor to be considered in the disc diffusion method. This method is well documented and standard zones of inhibition have been determined for susceptible and resistant values. Blank paper discs (Schleicher and Schuell, Spain) with a diameter of $8.0 \mathrm{~mm}$ were impregnated with $10 \mu \mathrm{l}$ of tested concentration of the stock solutions. When a filter paper disc impregnated with a tested chemical is placed on agar, the chemical will diffuse from the disc into the agar. This diffusion will place the chemical in the agar only around the disc. The solubility of the chemical and its molecular size will determine the size of the area of chemical infiltration around the disc. If an organism is placed on the agar, it will not grow in the area around the disc if it is susceptible to the chemical. This area of no growth around the disc is known as zone of inhibition or clear zone. For the disc diffusion, the zone diameters were measured [12], found that, agar based methods such test and disc diffusion can be good alternatives because they are simpler and faster than broth-based methods.

\section{Results and Disscussion}

\subsection{Elemental Analysis and Physical Properties}

The results of elemental analyses and physical properties of the free ligands and its metal chelates shown in Table 1 are in good agreement with those required by proposed formulae. The isolated solid complexes are stable at room temperature, partly soluble in organic solvents $\left(\mathrm{L}^{1}-\mathrm{L}^{2}\right)$, but completely soluble in DMF and DMSO. Based on the above mentioned results, it can propose the general structural formulae of the complexes (M:L) ratio 1:1 is represented in Figure 1 and Figure 2.

\subsection{Molar Conductivity Measurements}

The metal chelates were dissolved in DMF at $25^{\circ} \mathrm{C} \pm 2{ }^{\circ} \mathrm{C}$ and the molar conductivities of $5 \times 10^{-4} \mathrm{M}$ of their solutions were measured by recommended procedure [13]. The obtained molar conductance values are listed in Table 1. The molar conductivity value of $\mathrm{Co}(\mathrm{II}), \mathrm{Ni}(\mathrm{II})$ and $\mathrm{Cu}$ (II) chelates of free ligands $\left(\mathrm{L}^{1}\right.$ - $\mathrm{L}^{2}$ ) are found to be 5.20 up to $7.76 \Omega^{-1} \cdot \mathrm{mol}^{-1} \cdot \mathrm{cm}^{2}$. The chelates are nonionic in nature and they are considered as non-electrolytes.

\subsection{FT-IR Spectroscopy}

The main FT-IR bands of 2-acetyl-3-amino-1,4-naphthoquinone $\left(\mathrm{L}^{1}\right)$ and $\left(\mathrm{L}^{2}\right)$ and their corresponding metal chelates are presented in Table 2.

The vibration spectra of prepared ligand $\mathrm{L}^{1}$ exhibit a very broad band at 3433 $\mathrm{cm}^{-1}$ and at $3413 \mathrm{~cm}^{-1}$ assigned to the $v\left(\mathrm{NH}_{2}\right)$ stretching vibration of $\left(\mathrm{C} 2-\mathrm{NH}_{2}\right)$ of the naphthoquinone. The stretching band at $1624 \mathrm{~cm}^{-1}$ and at $1690 \mathrm{~cm}^{-1} \mathrm{can}$ be assigned to the $v(\mathrm{C}=\mathrm{O})$. The stretching band at $1577 \mathrm{~cm}^{-1}$ and at $1536 \mathrm{~cm}^{-1}$ can be assigned to the $v(\mathrm{C}-\mathrm{N})$. The vibration spectra of the prepared complexes of $\mathrm{L}^{1}$ exhibits a broad bands around 3548,3542 and $3553 \mathrm{~cm}^{-1}$ due to the $v(\mathrm{OH})$ 


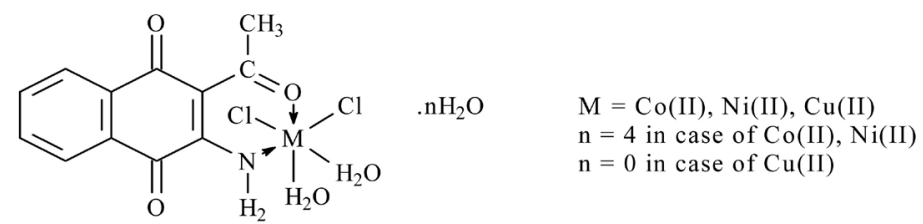

Figure 1. The proposed structure of the prepared metal complexes of 2-acetyl-3-amino1,4-naphthoquinon $\left(\mathrm{L}^{1}\right)$.

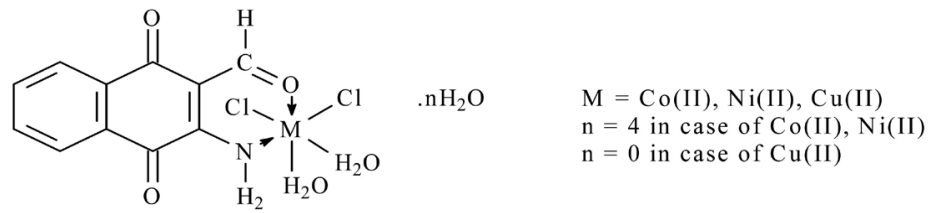

Figure 2. The proposed structure of the prepared metal complexes of 2-formyl-3-amino1,4-naphthoquinon $\left(\mathrm{L}^{2}\right)$.

Table 2. Infrared spectral data of free ligand $\left(\mathrm{L}^{1}-\mathrm{L}^{2}\right)$ and their metal chelates.

\begin{tabular}{|c|c|c|c|c|c|c|c|}
\hline Compound & $\begin{array}{c}v \\
\left(\mathrm{H}_{2} \mathrm{O}\right)\end{array}$ & $\begin{array}{c}v \\
\left(\mathrm{NH}_{2}\right)\end{array}$ & $\begin{array}{c}v \\
(\mathrm{C}=\mathrm{O})\end{array}$ & $\begin{array}{c}v \\
(\mathrm{C}-\mathrm{N})\end{array}$ & $\begin{array}{c}v \\
(\mathrm{C}=\mathrm{S})\end{array}$ & $\begin{array}{c}v \\
(\mathrm{M}-\mathrm{O})\end{array}$ & $\begin{array}{c}v \\
(\mathrm{M}-\mathrm{N})\end{array}$ \\
\hline $\mathrm{L}^{1}$ & - & $3433 b$ & $1624 w$ & $1577 \mathrm{~s}$ & - & - & - \\
\hline $\mathrm{L}^{1}+\mathrm{Co}(\mathrm{II})$ & $\begin{array}{c}3548 \mathrm{w} \\
808 \mathrm{~s}\end{array}$ & $3392 b$ & $1618 \mathrm{~s}$ & $1586 \mathrm{~s}$ & - & 582 & 472 \\
\hline $\mathrm{L}^{1}+\mathrm{Ni}(\mathrm{II})$ & $\begin{array}{c}3542 \mathrm{w} \\
868 \mathrm{~s}\end{array}$ & $3378 b$ & $1609 \mathrm{~s}$ & $1584 \mathrm{~s}$ & - & 578 & 469 \\
\hline $\mathrm{L}^{1}+\mathrm{Cu}(\mathrm{II})$ & $\begin{array}{c}3553 w \\
896 s\end{array}$ & $3355 b$ & $1616 \mathrm{w}$ & $1588 \mathrm{~s}$ & - & 586 & 467 \\
\hline $\mathrm{L}^{2}$ & - & $3413 b$ & $1690 \mathrm{~s}$ & $1536 \mathrm{~s}$ & - & - & - \\
\hline $\mathrm{L}^{2}+\mathrm{Co}(\mathrm{II})$ & $\begin{array}{c}3537 \mathrm{w} \\
987 \mathrm{~s}\end{array}$ & $3400 \mathrm{~b}$ & $1674 \mathrm{~s}$ & $1587 \mathrm{~s}$ & - & 572 & 469 \\
\hline $\mathrm{L}^{2}+\mathrm{Ni}(\mathrm{II})$ & $\begin{array}{c}3543 w \\
972 \mathrm{~s}\end{array}$ & $3370 \mathrm{~b}$ & $1680 \mathrm{~s}$ & $1583 \mathrm{~s}$ & - & 577 & 466 \\
\hline $\mathrm{L}^{2}+\mathrm{Cu}(\mathrm{II})$ & $\begin{array}{c}3539 w \\
924 s\end{array}$ & $3362 b$ & $1673 \mathrm{~s}$ & $1591 \mathrm{~s}$ & - & 583 & 468 \\
\hline
\end{tabular}

stretching, similarly L $\mathrm{L}^{2}$ exhibits a broad bands around 3537, 3543 and $3539 \mathrm{~cm}^{-1}$ due to the $v(\mathrm{OH})$ stretching. The lower shift of $v\left(\mathrm{NH}_{2}\right)$ band in at 3392, 3378 and $3355 \mathrm{~cm}^{-1}$ for $\mathrm{L}^{1}$ and 3400,3370 and $3362 \mathrm{~cm}^{-1}$ for $\mathrm{L}^{2}-\mathrm{Co}(\mathrm{II}) \mathrm{Ni}(\mathrm{II})$ and $\mathrm{Cu}$ (II) complexes support the contribution of $\mathrm{N}$-atom of $\mathrm{NH}_{2}$ group in complex formation. On complexation $\mathrm{L}^{1}$ show lower shift at 1618,1609 and $1616 \mathrm{~cm}^{-1}$ for $\mathrm{Co}(\mathrm{II}), \mathrm{Ni}$ (II) and $\mathrm{Cu}$ (II) ions respectively due to stretching vibration of $\mathrm{v}$ $(\mathrm{C}=\mathrm{O})$, which supports the involvement of oxygen atom of $(\mathrm{C}=\mathrm{O})$ group in chelation. In a similar fashion on complexation $\mathrm{L}^{2}$ show lower shift at 1674,1680 and $1673 \mathrm{~cm}^{-1}$ for $\mathrm{Co}(\mathrm{II}), \mathrm{Ni}(\mathrm{II})$ and $\mathrm{Cu}(\mathrm{II})$ ions respectively due to stretching vibration of $v(\mathrm{C}=\mathrm{O})$, which supports the involvement of oxygen atom of $(\mathrm{C}=\mathrm{O})$ group in chelation. Also on complexation of $\mathrm{L}^{1}$ and $\mathrm{L}^{2}$ with $\mathrm{Co}(\mathrm{II}), \mathrm{Ni}(\mathrm{II})$ and $\mathrm{Cu}$ (II) ions respectively, a red shift has been observed in $v(\mathrm{C}-\mathrm{N})$ stretching vi- 
bration at 1586, 1584 and $1588 \mathrm{~cm}^{-1}$ and at 1587, 1583 and $1591 \mathrm{~cm}^{-1}$ respectively which may be due to increase of bond order of carbon to the nitrogen link following the coordination of the imine nitrogen atom to metal ions. The stretching bands of the coordinated water molecules $v\left(\mathrm{H}_{2} \mathrm{O}\right)$ was observed at 808 , 868 and $896 \mathrm{~cm}^{-1}$ for $\mathrm{Co}(\mathrm{II}), \mathrm{Ni}(\mathrm{II})$ and $\mathrm{Cu}(\mathrm{II})-\mathrm{L}^{1}$ complexes and at 987, 972 and $924 \mathrm{~cm}^{-1}$ for $\mathrm{Co}(\mathrm{II}), \mathrm{Ni}(\mathrm{II})$ and $\mathrm{Cu}(\mathrm{II})-\mathrm{L}^{2}$ complexes. The new bands observed at 582, 578 and $586 \mathrm{~cm}^{-1}$ of $\mathrm{L}^{1}$ complexes assigned to $v(\mathrm{M}-\mathrm{O})$ and at 472 , 469 and $467 \mathrm{~cm}^{-1}$ assigned to $v(\mathrm{M}-\mathrm{N})$. Also new band are observed at 572, 577 and $583 \mathrm{~cm}^{-1}$ in all complexes of $\mathrm{L}^{2}$ under study assigned to $v(\mathrm{M}-\mathrm{O})$ and at 469 , 466 and $468 \mathrm{~cm}^{-1}$ assigned to $v(\mathrm{M}-\mathrm{N})$.

\section{4. ${ }^{1} \mathrm{H}-\mathrm{NMR}$ Measurements}

\subsection{1. ${ }^{1} \mathrm{H}-\mathrm{NMR}$ of 2-Acetyl-3-Amino-1,4-Naphthoqunone $\left(\mathrm{L}^{1}\right)$ and Its Cobalt Complex}

${ }^{1} \mathrm{H}-\mathrm{NMR}$ spectrum $300 \mathrm{MHz}$ of 2-acetyl-3-amino-1,4-naphthoqunone $\left(\mathrm{L}^{1}\right)$ shows several signals and the resulted data are tabulated in Table 3.

The ${ }^{1} \mathrm{H}$ NMR spectrum $\left(\mathrm{L}^{1}\right)$ shows a singlet signal at $\delta 2.5 \mathrm{ppm}$ of relative intensity $(\mathrm{s}, 3 \mathrm{H})$ may be attributed to $\mathrm{CH}_{3}$ protons, a multiplet at $\delta 7.2-7.5 \mathrm{ppm}$ of relative intensity $4 \mathrm{H}$, may be assigned to four protons $(\mathrm{m}, 4 \mathrm{H})$ in quinone, $\mathrm{H}_{\text {arm }}$. The multiplet signal observed at $\delta 8 \mathrm{ppm}$ may be assigned to two protons of amino group $\left(\mathrm{m}, 2 \mathrm{H}, \mathrm{NH}_{2}\right)$ [14].

On comparing the investigated ${ }^{1} \mathrm{H}-\mathrm{NMR}$ signals of the cobalt chelate $\left[\mathrm{CoC}_{12} \mathrm{H}_{9} \mathrm{NO}_{3} \mathrm{Cl}_{2} \cdot\left(\mathrm{H}_{2} \mathrm{O}\right)_{2}\right] \cdot 4 \mathrm{H}_{2} \mathrm{O}$ with those of the $\mathrm{L}^{1}$ ligand protons signals, multiplets and the chemical shifts. It has been found that methyl protons of the free ligand are slightly shifted to $\delta 2.49 \mathrm{ppm}$. Also the $\mathrm{NH}_{2}$ protons of the free ligands are slightly shifted to $\delta 7.7 \mathrm{ppm}$ this suggests that the metal ion coordination takes place through the nitrogen atom of $\mathrm{NH}_{2}$ group. The proton signal observed at $\delta 3.52 \mathrm{ppm}$, which may be assigned to the presence of water molecules is in agreement with the suggested formulae of metal chelates.

\subsection{2. ${ }^{1} \mathrm{H}-\mathrm{NMR}$ of 2-Formayl-3-Amino-1,4-Naphthoqunone $\left(\mathrm{L}^{2}\right)$ and Its Nickel Complex}

${ }^{1} \mathrm{H}$-NMR spectrum $300 \mathrm{MHz}$ of 2-formayl-3-amino-1,4-naphthoqunone ( $\left.\mathrm{L}^{2}\right)$ shows several signals and the resulted data are tabulated in Table 3.

The ${ }^{1} \mathrm{H}$ NMR spectrum $\left(\mathrm{L}^{2}\right)$ shows a singlet signal at $\delta 9.6 \mathrm{ppm}$ of relative intensity $(\mathrm{s}, 1 \mathrm{H})$ may be attributed to $\mathrm{CHO}$ protons, a multiplet at $\delta 7.13-7.5 \mathrm{ppm}$ of relative intensity $4 \mathrm{H}$, which may be assigned of four protons (m, $4 \mathrm{H}$ ) in quinone, $\mathrm{H}_{\text {arm }}$.

Table 3. ${ }^{1} \mathrm{H}-\mathrm{NMR}$ data for free ligands $\left(\mathrm{L}^{1}-\mathrm{L}^{2}\right)$ and their metal chelates.

\begin{tabular}{cccccc}
\hline Compound & $\delta \mathrm{CH}_{3}$ & $\delta \mathrm{CHO}$ & $\delta \mathrm{H}_{2} \mathrm{O}$ & $\delta(\mathrm{Ar}-\mathrm{H})$ & $\delta \mathrm{NH}_{2}$ \\
\hline $\mathrm{L}^{1}$ & 2.50 & - & - & $7.2-7.5$ & 8.0 \\
$\mathrm{~L}^{1}+\mathrm{Co}(\mathrm{II})$ & 2.49 & - & 3.52 & $6.6-7.2$ & 7.7 \\
$\mathrm{~L}^{2}$ & - & 9.6 & - & $7.13-7.50$ & 8.4 \\
$\mathrm{~L}^{2}+\mathrm{Ni}(\mathrm{II})$ & - & 9.5 & 3.18 & $7.0-7.33$ & 7.8 \\
\hline
\end{tabular}


The multiplet signal observed at $\delta 8.4 \mathrm{ppm}$ may be assigned to two protons of amino group $\left(\mathrm{m}, 2 \mathrm{H}, \mathrm{NH}_{2}\right)$ [15].

The comparison of the protons signals, multiplets and the chemical shifts of $\mathrm{L}^{2}$ ligand with its corresponding nickel chelate $\left[\mathrm{NiC}_{11} \mathrm{H}_{7} \mathrm{NO}_{3} \mathrm{Cl}_{2} \cdot\left(\mathrm{H}_{2} \mathrm{O}\right)_{2}\right] \cdot 4 \mathrm{H}_{2} \mathrm{O}$ is investigated. It has been found that the aldehyde $\mathrm{CHO}$ protons of the free ligand are slightly shifted to $\delta 9.4 \mathrm{ppm}$. Also the $\mathrm{NH}_{2}$ protons of the free ligands are slightly shifted to $\delta 7.8 \mathrm{ppm}$ this suggests that the metal ion coordination takes place through the nitrogen atom of $\mathrm{NH}_{2}$ group. The proton signal is observed at $\delta$ $3.18 \mathrm{ppm}$, which may be assigned to the presence of water molecules is in agreement with the suggested formulae of metal chelates. The ${ }^{1} \mathrm{H}-\mathrm{NMR}$ spectrum of 2-formayl-3-amino-1,4-naphthoqunone nickel chelate shows several characteristic signals.

\subsection{Mass Spectroscopic Studies}

\subsubsection{Mass Spectra of 2-Acetyl-3-Amino-1,4-Naphthoqunone $\left(\mathrm{L}^{1}\right)$ and Its Copper Complex}

The electron impact mass spectrum of $\left[\mathrm{CuC}_{12} \mathrm{H}_{9} \mathrm{NO}_{3} \mathrm{Cl}_{2}\left(\mathrm{H}_{2} \mathrm{O}\right)_{2}\right]$ Figure 3 shows many fragment ions which consists of two principle pathways as shows in Scheme 1 . The signal that appears at $\mathrm{m} / \mathrm{z}=385.05$ (mole mass $=385.68$ ) may be referred to the appearance of main general molecular weight of metal chelate which undergo two pathways of fragmentation. Pathway I stated that; the main metal chelates lose two molecules of water leaving a fragment at $\mathrm{m} / \mathrm{z}=352.86$ (mole mass $=349.65, \mathrm{RI}=36 \%$ ) followed by the appearance of a signal at $\mathrm{m} / \mathrm{z}=$ 176.68 (mole mass $=174.64, \mathrm{RI}=4 \%$ ); which may be refer to the loss of $\mathrm{C}_{7} \mathrm{H}_{4} \mathrm{O}$ (cyclohexa-1,3-dien-5-yne-1-carbaldehyde) and $\mathrm{Cl}_{2}$ followed by the appearance

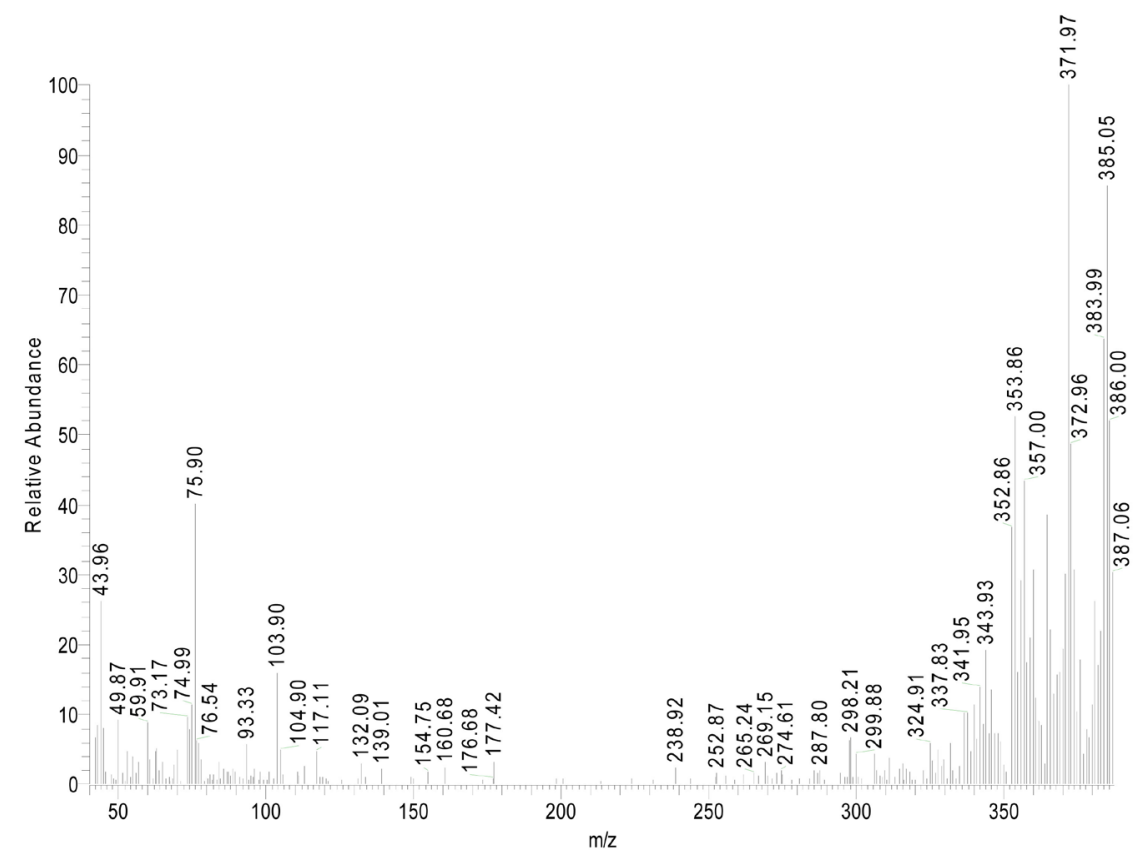

Figure 3. Mass Spectrum of $\left[\mathrm{Cu} \mathrm{L}^{1} \mathrm{Cl}_{2}\left(\mathrm{H}_{2} \mathrm{O}\right)_{2}\right]$. 


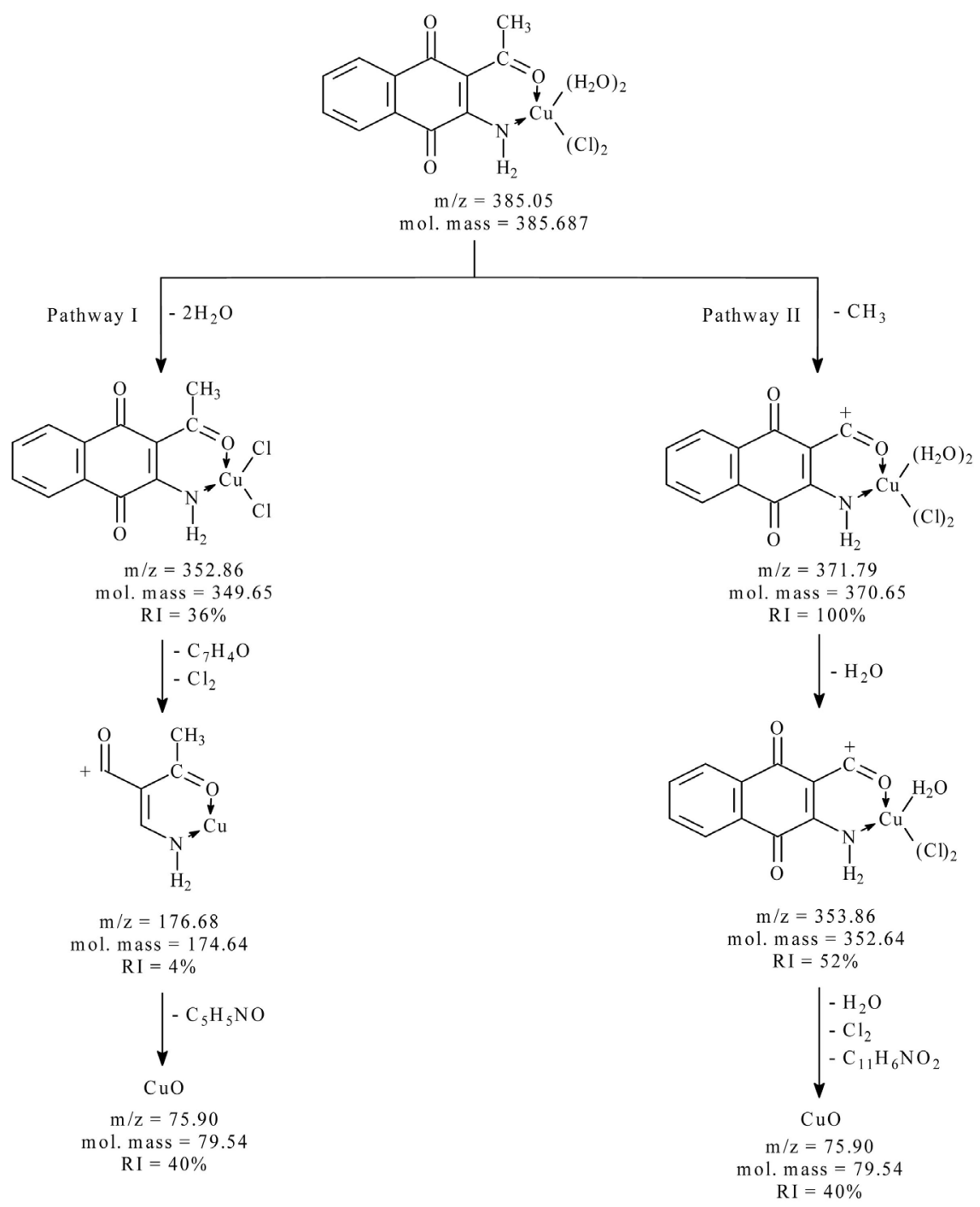

Scheme 1. The mass fragmentation pathways of copper complex with $\left(\mathrm{L}^{1}\right)$.

of a signal at $\mathrm{m} / \mathrm{z}=75.90$ (mole mass $=79.54, \mathrm{RI}=40 \%$ ) as rupture of $\mathrm{C}_{5} \mathrm{H}_{5} \mathrm{NO}$ (4-Hydroxypyridine) from the fragment. Pathway II shows a fragment at $\mathrm{m} / \mathrm{z}=$ 371.79 (mole mass $=370.65, \mathrm{RI}=100 \%$ ); which may be refer to the loss of $\mathrm{CH}_{3}$, followed by the appearance of a signal at $\mathrm{m} / \mathrm{z}=353.86$ (mole mass $=352.64, \mathrm{RI}=$ $52 \%$ ); which may be refer to the loss of one molecules of water, $\mathrm{Cl}_{2}$ and $\mathrm{C}_{11} \mathrm{H}_{6} \mathrm{NO}_{2}$ (furo[2,3-b]quinolin-8-olate) leaving a fragment give a signal at $\mathrm{m} / \mathrm{z}=$ 75.90 (mole mass $=79.54, \mathrm{RI}=40 \%$ ).

\subsubsection{Mass Spectra of 2-Formyl-3-Amino-1,4-Naphthoqunone $\left(\mathrm{L}^{2}\right)$ and Its Copper Complex}

The electron impact mass spectrum of $\left[\mathrm{CuC}_{11} \mathrm{H}_{7} \mathrm{NO}_{3} \mathrm{Cl}_{2} \cdot\left(\mathrm{H}_{2} \mathrm{O}\right)_{2}\right]$ shows many fragment ions which consists of two principle pathways as shows in Scheme 2. The signal that appears at $\mathrm{m} / \mathrm{z}=371.29$ (mole mass $=371.66$ ) may be referred to the appearance of main general molecular weight of metal chelate which undergo two pathways of fragmentation. Pathway I stated that; the main metal chelate 


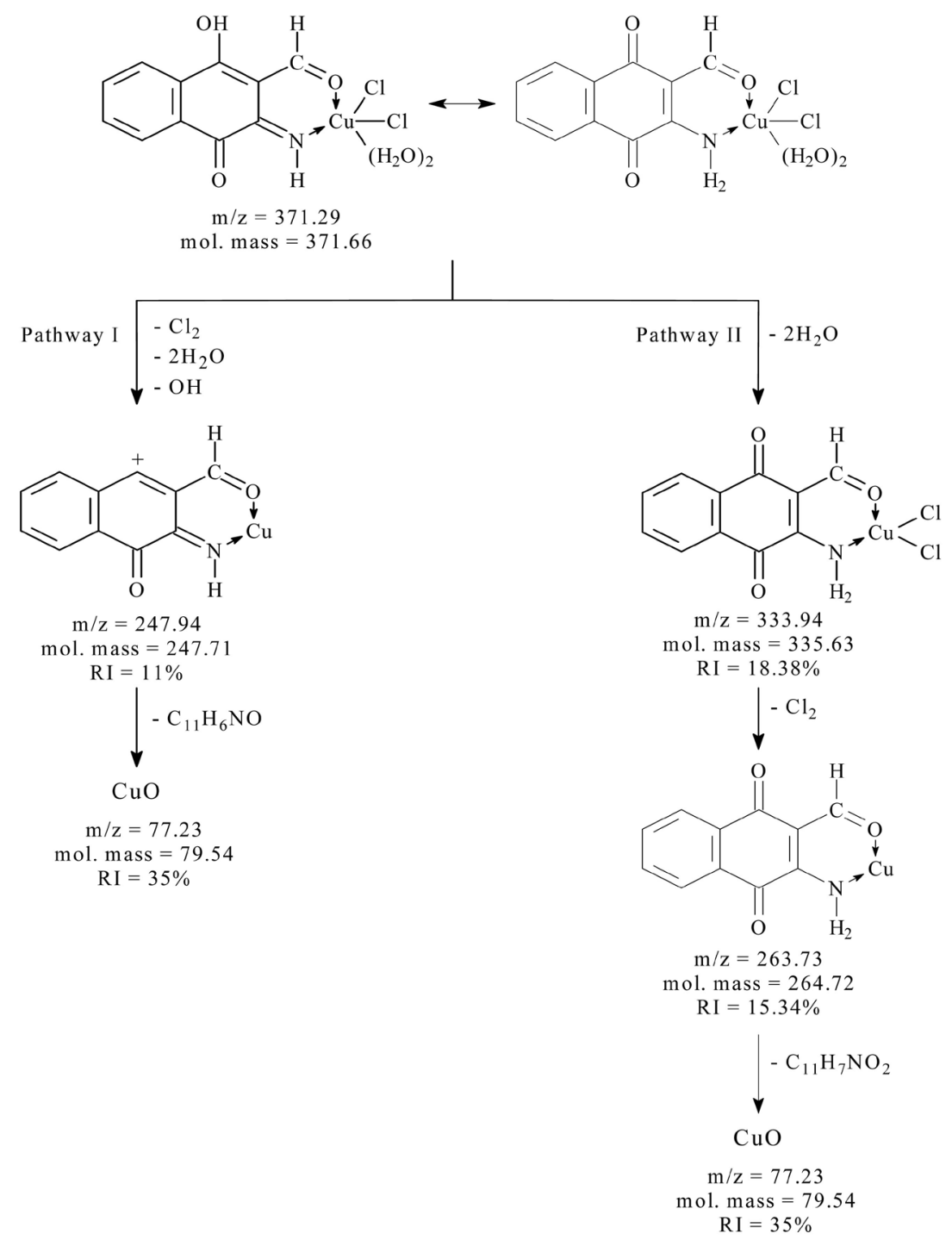

Scheme 2. The mass fragmentation pathways of copper complex with $\left(\mathrm{L}^{2}\right)$.

lose two molecules of water, hydroxyl ion and $\mathrm{Cl}_{2}$ leaving a fragment at $\mathrm{m} / \mathrm{z}=$ 247.94 (mole mass $=247.71, \mathrm{RI}=11 \%$ ) followed by the appearance of a signal at $\mathrm{m} / \mathrm{z}=77.23$ (mole mass $=79.54, \mathrm{RI}=35 \%$ ); which may be refer to the loss of $\mathrm{C}_{11} \mathrm{H}_{6} \mathrm{NO}$ (furo[2,3-b]quinolin-8-olate). Pathway II shows a fragment at $\mathrm{m} / \mathrm{z}=$ 333.94 (mole mass $=335.63, \mathrm{RI}=18.38 \%$ ); which may be refer to the loss of two molecules of water, followed by the appearance of a signal at $\mathrm{m} / \mathrm{z}=263.73$ (mole mass $=264.72, \mathrm{RI}=15.34 \%$ ); which may be refer to the loss of $\mathrm{Cl}_{2}$, followed by the appearance of a signal at $\mathrm{m} / \mathrm{z}=77.23$ (mole mass $=69.54, \mathrm{RI}=35 \%$ ) as rupture of $\mathrm{C}_{11} \mathrm{H}_{7} \mathrm{NO}$ (1,4-dioxo-2,3-dihydrona-phthalene-2-carbonitrile) from the fragment.

\subsection{Thermogravimetric Analyses (TGA)}

The TGA thermal analyses data of the synthesized metal chelates are tabulated in Table 4. 
Table 4. Thermoanalytical analyses data for newly synthesized chelates of ligands $\left(\mathrm{L}^{1}\right.$ $\left.\mathrm{L}^{2}\right)$.

\begin{tabular}{cccc}
\hline Compound & Temp range $^{\circ} \mathrm{C}$ & \% Mass loss found (calcd) & Assignment \\
\hline$\left[\mathrm{Cu} \mathrm{L}^{1} \mathrm{Cl}_{2}\left(\mathrm{H}_{2} \mathrm{O}\right)_{2}\right]$ & $50-300$ & $24.75(27.72)$ & - - oss of $2 \mathrm{H}_{2} \mathrm{O}, \mathrm{Cl}_{2}$ \\
& $300-1000$ & $50.38(51.65)$ & -Loss of $\mathrm{C}_{12} \mathrm{H}_{9} \mathrm{NO}_{2}$ \\
{$\left[\mathrm{Cu} \mathrm{L}^{2} \mathrm{Cl}_{2}\left(\mathrm{H}_{2} \mathrm{O}\right)_{2}\right]$} & $50-200$ & $25.46(28.77)$ & - Loss of $2 \mathrm{H}_{2} \mathrm{O}, \mathrm{Cl}_{2}$ \\
& $200-1000$ & $48.91(49.82)$ & -Loss of $\mathrm{C}_{11} \mathrm{H}_{7} \mathrm{NO}_{2}$ \\
\hline
\end{tabular}

\subsubsection{Thermal Analysis of 2-Acetyl-3-Amino-1,4-Naphthoqunone ( $\left.\mathrm{L}^{1}\right)$ - Cu Complex}

The TGA curve is refers to the thermal degradation process of $\left[\mathrm{CuL}^{1} \mathrm{Cl}_{2} \cdot\left(\mathrm{H}_{2} \mathrm{O}\right)_{2}\right]$ complex which occurs in two successive stages within the temperature range of $50^{\circ} \mathrm{C}-1000^{\circ} \mathrm{C}$. The first stage of decomposition starts at $50^{\circ} \mathrm{C}$ and end at $300^{\circ} \mathrm{C}$. The weight loss corresponds to the removal of two coordinated water molecules and $\mathrm{Cl}_{2}$ gas. The experimental mass loss of $24.75 \%$ agrees well with the calculated mass loss of $27.72 \%$. The final stage of decomposition reveals that the complex was then further decomposed within $300^{\circ} \mathrm{C}-1000^{\circ} \mathrm{C}$. This corresponds to the complete decomposition of the organic portion of the ligand. The observed mass loss value of $50.38 \%$ in this stage is in good agreement with the calculated mass loss value of $51.65 \%$ and the final product is quantitatively proved to be copper oxide. The total experimental mass loss $75.13 \%$ agrees well with the calculated mass loss of 79.37\%. All results are shown in Table 4.

\subsubsection{Thermal Analysis of 2-Formyl-3-Amino-1,4-Naphthoqunone ( $\left.L^{2}\right)$ - Cu Complex}

The thermogram of the complex $\left[\mathrm{CuL}^{2} \mathrm{Cl}_{2} \cdot\left(\mathrm{H}_{2} \mathrm{O}\right)_{2}\right]$ displays two stages of decomposition within the temperature range of $50^{\circ} \mathrm{C}-1000^{\circ} \mathrm{C}$. The first stage of decomposition between $50^{\circ} \mathrm{C}$ and $450^{\circ} \mathrm{C}$ corresponds to loss of two coordinated water molecules and $\mathrm{Cl}_{2}$ gas. The experimental mass loss of $25.46 \%$ agrees well with the calculated mass loss of $28.77 \%$. Step two starts at $200^{\circ} \mathrm{C}$ and comes to end at $1000^{\circ} \mathrm{C}$ corresponding to mass loss range $48.91 \%$ (calcd $\left.=49.82 \%\right)$ due to decomposition of the remaining organic ligand molecule. The mass losses are in agreement with calculated mass loss based on the obtained data (Table 4). The final residue is quantitatively proved to be copper(II) oxide. The total experimental mass loss $74.37 \%$ agrees well with the calculated mass loss of $78.60 \%$.

\section{Biological Activity}

The comparison of biological activity of the free ligands $\left(\mathrm{L}^{1}\right.$ up to $\left.\mathrm{L}^{2}\right)$ and its complexes with the standard disc of Ampicillin (antibacterial $\mathrm{G}^{+}$agent and antibacterial $\mathrm{G}^{-}$agent), Amphotericin $\mathrm{B}$ (antifungal agent), towards the different organisms was carried out. The data are listed in Table 5 and shown in Figure 4 and Figure 5. The free ligands and its metal chelates were screened against Staphylococcus aureus and Bacillis subtilis (G+) and Escherichia coli (G-) bacteria and candida albicans (fungi) to assess their potential antimicrobial agents. 


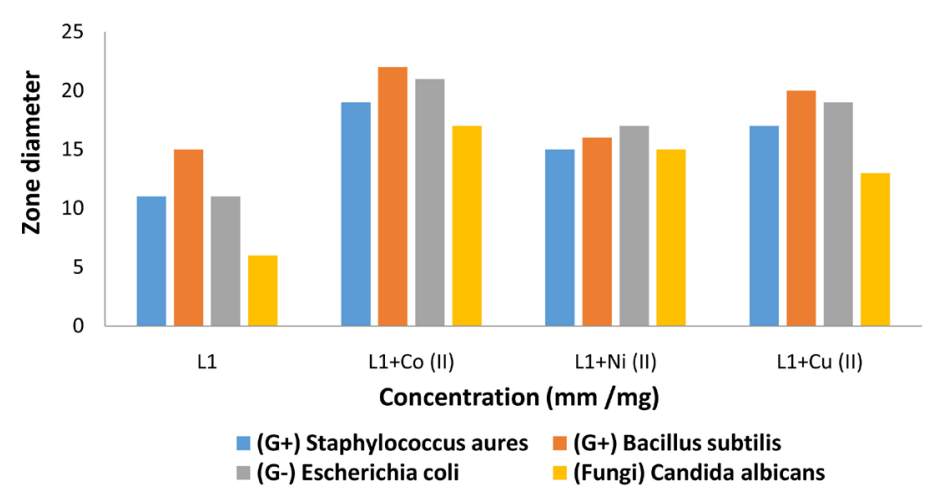

Figure 4. Biological activity of $\left(\mathrm{L}^{1}\right)$ and its metal complexes.

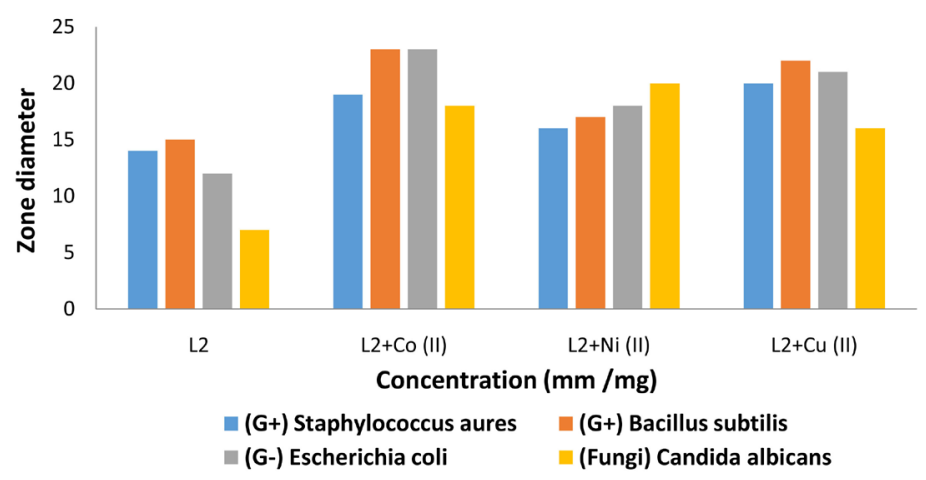

Figure 5. Biological activity of $\left(\mathrm{L}^{2}\right)$ and its metal complexes.

Table 5. Biological activity of $\mathrm{L}^{1}$ and $\mathrm{L}^{2}$ its metal chelates.

\begin{tabular}{ccccc}
\hline \multirow{2}{*}{$\begin{array}{c}\text { Organism } \\
\text { sample }\end{array}$} & \multicolumn{4}{c}{ Inhibition zone diameter $(\mathrm{mm} / \mathrm{mg}$ sample) } \\
\cline { 2 - 5 } & Staphylococcus aures & Bacillus subtilis & Escherichia coli & Candida albicans \\
\hline DMSO & 0 & 0 & 0 & 0 \\
$\mathrm{~L}^{1}$ & 11 & 15 & 11 & 6 \\
$\mathrm{~L}^{1}+\mathrm{Co}$ & 19 & 22 & 21 & 17 \\
$\mathrm{~L}^{1}+\mathrm{Ni}$ & 15 & 16 & 17 & 15 \\
$\mathrm{~L}^{1}+\mathrm{Cu}$ & 17 & 20 & 19 & 13 \\
$\mathrm{~L} 2$ & 14 & 15 & 12 & 7 \\
$\mathrm{~L}^{2}+\mathrm{Co}$ & 19 & 23 & 23 & 18 \\
$\mathrm{~L}^{2}+\mathrm{Ni}$ & 16 & 17 & 18 & 20 \\
$\mathrm{~L}^{2}+\mathrm{Cu}$ & 20 & 22 & 21 & 16 \\
\hline
\end{tabular}

\subsection{Biological Activity of 2-Acetyl-3-Amino-1,4-Naphthoqunone}

$\left(\mathrm{L}^{1}\right)$

The biological activity of Ligand (2-Acetyl-3-Amino-1,4-Naphthoquinone) $\mathrm{L}^{1}$ and its metal complexes Figure 4 shows higher results than that of the free ligand. But all of them are lower than standard. Therefore, the biological activity of the complexes follow the order $\mathrm{Co}(\mathrm{II})>\mathrm{Cu}(\mathrm{II})>\mathrm{Ni}$ (II) against Staphylococcus aureus, Bacillus subtilis and Escherichia coli organisms. But with Candida albicans the biological activity follows the order $\mathrm{Co}(\mathrm{II})>\mathrm{Ni}(\mathrm{II})>\mathrm{Cu}(\mathrm{II})$. 


\subsection{Biological Activity of 2-Formyl-3-Amino-1,4-Naphthoqunone $\left(\mathrm{L}^{2}\right)$}

The biological activity of Ligand (2-formyl-3-amino-1,4-naphthoqunone) $\mathrm{L}^{2}$ and its metal complexes Figure 5 shows higher results than that of the free ligand. But all of them are lower than standard. Therefore, the biological activity of the complexes follow the order $\mathrm{Co}(\mathrm{II})>\mathrm{Cu}(\mathrm{II})>\mathrm{Ni}$ (II) against Bacillus subtilis and Escherichia coli organisms for $\left(\mathrm{L}^{2}\right)$ and complexes Meanwhile, the biological activity of the complexes follow the order $\mathrm{Cu}(\mathrm{II})>\mathrm{Co}(\mathrm{II})>\mathrm{Ni}$ (II) against Staphylococcus aureus. But with candida albicans the biological activity follows the order $\mathrm{Ni}(\mathrm{II})>\mathrm{Co}(\mathrm{II})>\mathrm{Cu}(\mathrm{II})$.

The importance of this, lies in the fact that these complexes could be applied fairly in the treatment of some common diseases caused by $E$. coli e.g. Septicemia, Gastroenteritis, Urinary tract infections and hospital acquired infections according to [16]. However, the complexes were specialized in inhibiting Gram-positive and Gram-negative bacterial strains. The importance of this unique property of the investigated complexes lies in the fact that, it could be applied safely in the treatment of infections caused by any of these particular strains. Generally, the activity of the free ligand was increased upon complexation with metal ions; the enhancement in activity can be explained on the basis of chelation theory, reported by [17] [18]. Chelation reduces the polarity of the metal ion considerably, mainly because of the partial sharing of its positive charge with donor groups and the possible p electron delocalization over the whole chelate ring. Chelation not only reduces the polarity of metal ion, but also increases the lipophilic character of the chelate. As a result of this, the interaction between the metal ion and the cell walls is favored, resulting in interference with normal cell processes.

\section{Conclusion}

In the present study, the free ligands (L1, L2) and its metal complexes Co(II), $\mathrm{Ni}(\mathrm{II})$ and $\mathrm{Cu}$ (II) were prepared and structurally identified. The structures of free ligands and its metal chelates are proved by elemental analyses and applying spectroscopic measurements (FT-IR, H-NMR, and mass spectra) and confirmed by thermal analyses. The synthesized free ligands are found to be biologically active and their metal complexes showed significantly enhanced antibacterial and antifungal activities against microbial strains in comparison to the free ligand.

\section{Conflicts of Interest}

The authors declare that they have no conflict of interest.

\section{References}

[1] Shor, E. and Perlin, D.S. (2015) Coping with Stress and the Emergence of Multidrug Resistance in Fungi. PLOS Pathogens, 3, 11.

https://doi.org/10.1371/journal.ppat.1004668

[2] Micek, S.T., Wunderink, R.G., Kollef, M.H., Chen, C., et al. (2015) An International 
Multicenter Retrospective Study of Pseudomonas aeruginosa Nosocomial Pneumonia: Impact of Multidrug Resistance. Critical Care, 19, 219.

https://doi.org/10.1186/s13054-015-0926-5

[3] López López, L.I., Nery Flores, S.D., Silva Belmares, S.Y. and Sáenz Galindo, A. (2014) Naphthoquinones: Biological Properties and Synthesis of Lawsone and Derivatives-A Structured Review. Vitae, 21, 248-258.

[4] Kumagai, Y., Shinkai, Y., Miura, T. and Cho, A.K. (2012) The Chemical Biology of Naphthoquinones and Its Environmental Implications. Annual Review of Pharmacology and Toxicology, 52, 221-247. https://doi.org/10.1146/annurev-pharmtox-010611-134517

[5] Lopez, L.I., Leyva, E. and Garcia, R. (2011) Las naftoquinonas: Ma's que pigmentos naturales. Revista Mexicana de Ciencias Farmacéuticas, 42, 6-17.

[6] Adriano, D.B., Márcia, M. and Valter, S. (2004) Annelise Engel Gerbase Revista Brasileira de Ciências Farmacêuticas. Brazilian Advances in Free Radical Biology and Medicine, 2, 211-279.

[7] Mohanty, S.K., Sridhar, R. and Padmanvan, S.Y. (1977) Synthesis of 3-Substituted Benzpyrid-4-imino-2-oxime Derivative. Indian Journal of Chemistry, 158, 1146.

[8] Makoto, O., Teijiro, K. and Tumeaki, H. (1998) Organic Colorants, a Handbook of Selected Dyes for Electro-Optical Application. Elsevier Science Publishers, Madison.

[9] Bauer, A.W., Kirby, W.M., Sherris, C. and Turck, M. (1996) Antibiotic Susceptibility Testing by a Standardized Single Disk Method. American Journal of Clinical Pathology, 45, 493. https://doi.org/10.1093/ajcp/45.4 ts.493

[10] Pfaller, M.A., Burmeister, L., Bartlett, M.A. and Rinaldi, M.G. (1988) Multicenter Evaluation of Four Methods of Yeast Inoculum Preparation. Journal of Clinical Microbiology, 26, 1437. https://doi.org/10.1128/JCM.26.8.1437-1441.1988

[11] Liebowitz, L.D., Ashbee, H.R., Evans, E.G.V., Chong, Y., Mallatova, N. and Zaidi, M. (2001) A Two-Year Global Evaluation of the Susceptibility of Candida Species to Fluconazole by Disk Diffusion. Diagnostic Microbiology and Infectious Disease, 40, 27-33. https://doi.org/10.1016/S0732-8893(01)00243-7

[12] Matar, M.J., Ostrosky-Zeichner, L., Paetznick, V.L., Rodriguez, J.R., Chen, E. and Rex, J.H. (2003) Correlation between E-Test, Disk Diffusion, and Microdilution Methods for Antifungal Susceptibility Testing of Fluconazole and Voriconazole. Antimicrobial Agents and Chemotherapy, 47, 1647-1651. https://doi.org/10.1128/AAC.47.5.1647-1651.2003

[13] Geary, W.J. (1971) The Use of Conductivity Measurements in Organic Solvents for the Characterisation of Coordination Compounds. Coordination Chemistry Reviews, 7, 81-122. https://doi.org/10.1016/S0010-8545(00)80009-0

[14] Gomaa, M.M. (2001) The Molecular Design and Optical Characterization of Characterization of Some Novel Condensed and Bridge Head Heterocyclic Quinine Dyes. PhD Thesis, South Valley University, Chikankata.

[15] Batterham, T.J. (1973) NMR Spectra of Simple Heterocycles. Wiley, New York, 30, 348.

[16] Jawetz, E., Melnick, J.L. and Adelberg, E.A. (1979) Review of Medical Microbiology. 16th Edition, Lang Medical Publications, Los Angeles.

[17] Mohamed, G.G., Omar, M.M. and Ebrahim, A.A. (2010) Preparation, Characterization and Biological Activity of Novel Metal-NNNN Donor Schiff Base Complexes. Spectrochimica Acta Part A, 75, 678-685. https://doi.org/10.1016/j.saa.2009.11.039 
[18] Murukan, B. and Mohanan, K. (2007) Synthesis, Characterization and Antibacterial Properties of Some Trivalent Metal Complexes with [(2-hydroxy-1-naphthaldehyde)3-isatin]-bishydra-zone. Journal of Enzyme Inhibition and Medicinal Chemistry, 22, 65-70. https://doi.org/10.1080/14756360601027373 